\title{
FUTURE LABOUR MARKET DEMAND IN VIDZEME REGION, LATVIA
}

\section{Sarmite Rozentale, Agita Livina, Sandra Brigsa, Aigars Andersons, Ieva Kreituze}

\author{
Faculty of Society and Science, Vidzeme University of Applied Sciences, Cesu Str. 4, Valmiera, Latvia \\ E-mails: sarmite.rozentale@va.lv(correspondingauthor); agita.livina@va.lv; \\ sandra.brigsa@va.lv; aigars.andersons@va.lv;ieva.kreituze@va.lv
}

\begin{abstract}
The objective of the study was to identify employers' needs of the future labour market in 5-7 years in Vidzeme Region. The data were obtained from a quantitative survey of employers and expert interviews according to Delphi method. Experts believe that some brand new profession may appear, but mostly changes will affect the contents of the professions and the required skills.

As regards the topicality of occupations within the next five years, the experts all agree on priority of information and communication services and related professions. The second most frequently mentioned is the processing industry, since a change in the working specifics will require employees, able to use complicated equipment.
\end{abstract}

Keywords: future, forecast, labour market demand, business, technological progress, skills.

JEL Classification: J23; J21; C10.

\section{Introduction}

During the recent years there has been a rapid change in the labour market. Simultaneously to quantitative changes, the labour market is increasingly affected by qualitative changes (Brynjolfsson, Saunders 2010). There are many areas where human labour is replaced by machines. It does not happen overnight. Machinery has been replacing the human labour since the $19^{\text {th }}$ century (Rifkin 1995). Over time, these changes are becoming increasingly dominant (Bresnahan et al. 2002).

HR is at a crossroads, as technology can now accomplish many of those traditional responsibilities faster, cheaper, and better than before (Lindzon 2015). The labour market is divided between technologies and highly qualified workforce.

Machines have improved the quality of life and human well-being; however, not the wellbeing of people who earn living by manual jobs. Over time, the nature of human skills changes, which originally was a profession, but is increasingly becoming a machine label. The labour market is divided between people and machines. People need to focus on skills that offer a competitive advantage while leaving the work for the machines where they are better equipped. It is difficult to automate such activities as business, research, the work of babysitters, nurses and waiters in a restaurant.

Compared to the past, the areas where the transformation of the labour market is taking place have changed. After the industrial revolution there have never been such rapid changes in the workforce and society as now. Employers increasingly signal that the labour supply is not changing according to the needs of entrepreneurs. Certain professions become less and less demanded, but others lack competent workers.

These processes are not topical only in Latvia. Overall $35 \%$ of the population in the UK fewer than 20 years of age are in the zone of substitution, while in London it is $30 \%$.

Innovations will require a change of professions related to administration and indirect management to professions requiring IT, management and creative skills. Occupations considered to be in high-risk zone are the ones related to basic tasks in office, administrative support, transportation. Low risk professions are considered to be those related to senior management, budget administration, designing, science, training, legal administration, employee insurance, human experience expressions and the media as well as social insurance. Experts expect that by 2025 automation and robots will have taken over almost $30 \%$ of our jobs, and even managers are not protected (Krone et al. 2016).

However, if artificial intelligence and robotics continue on their present trend, future machines will be able to carry out these human capabilities, at least in certain contexts and to a certain extent (Mokyr et al. 2015). Thus, it seems frighteningly 
plausible that this time will be different, and large sections of the labour market will be dislocated or "hollowed out" (Katz, Margo 2013).

These issues are also discussed by American Professor of Digital Business Centre (MIT) director Erik Brynjolfsson in the book "The Second Machine Age: Work, Progress, and Prosperity in a Time of Brilliant Technologies". His study helps to see the world of tomorrow through an exponential rather than arithmetic lens. The author believes that massive technological innovation will radically affect our world, and we need to develop new business models, new technology and new policies to deepen our human capabilities, so that each person could remain economically viable in an era when automation is increasing (Brynjolfsson, McAfee 2014). New technologies can save our economy, but can also endanger our living. Martin Ford in his book "Rise of the Robots: Technology and the Threat of a Jobless Future" gives a warning that we will face massive unemployment and economic collapse if we do not make radical changes, such as offering people basic salary as guaranteed income. He believes that many highly educated people such as lawyers, radiologists, software developers will lose jobs as a result of automation (Ford 2015).

Dr Maarten Goos has also focused on the research of the future labour market. His research focuses on the interplay between technology and society, including various aspects of the labour market, including polarization of the labour market, the impact of technological progress on the labour market, labour inequality and digital platforms. He works closely with scientists from other disciplines such as engineering, medicine, biology, history, law and ethics, as well as policy makers. Formation of society in the future and the empowerment of the European economy and its institutions for the digital age are the central issues in his research (Goos 2013; Goos, Manning 2007).

Today, we are on the cusp of a Fourth Industrial Revolution. Developments in genetics, artificial intelligence, robotics, nanotechnology, 3D printing and biotechnology, to name just a few, are all building on and amplifying one another. This will lay the foundation for a revolution, more comprehensive and all-encompassing than anything we have ever seen. Smart systems- homes, factories, farms, grids or cities-will help tackle problems ranging from supply chain management to climate change. The rise of the sharing economy will allow people to monetize everything from their empty house to their car. While the impending change holds great promise, the patterns of consumption, production and employment created by it also pose major challenges requiring proactive adaptation by corporations, governments and individuals. Concurrent to the technological revolution is a set of broader socio-economic, geopolitical and demographic drivers of change, each interacting in multiple directions and intensifying one another. As entire industries adjust, most occupations are undergoing a fundamental transformation. While some jobs are threatened by redundancy and others grow rapidly, the existing jobs are also going through a change in the skill sets required to do them (World Economic Forum 2016; OECD 2015).

These issues are also discussed by Markus Lorenz. Industrial production was transformed by steam power in the nineteenth century, electricity in the early twentieth century, and automation in the 1970s. These waves of technological advancement did not reduce overall employment, however. Although the number of manufacturing jobs decreased, new jobs emerged and the demand for new skills grew. Today, another workforce transformation is on the horizon as manufacturing experiences a fourth wave of technological advancement: the rise of new digital industrial technologies that are collectively known as Industry 4.0. To analyse the quantitative effects on the industrial workforce, we studied how the ten most influential use cases for these foundational technologies will affect the evolution of 40 job families in 23 industries in Germany (see Fig. 1) (Lorenz et al. 2015).

Now, though, we are in the midst of a fourth wave of technological advancement: the rise of new digital industrial technology known as Industry 4.0 , a transformation that is powered by nine foundational technology advances (see Fig. 2) (Rüßmann et al. 2015).

Robots and other technologies are transforming supply chains, tracking items from source to consumer, minimizing shipping time and cost, automating clerical tasks, and more. But are they eliminating the need for human workers, leading to persistent technological unemployment?

Surprisingly, the managers of warehouses and other supply chain facilities report that they have difficulty hiring enough workers with sufficient skills needed to use the new technologies. Moreover, they see these skill shortages persisting for the next decade (Bessen 2015).

What is unique about today's digital revolution is the suspicion, fanned by progressives, that for the first time technology threatens to make obsolete not only some jobs- as assemblyline robotics has, for instance, but human labour itself. The fear is that we are entering an era 
when sophisticated software will leave only the most intelligent with high-paying jobs (Lewis 2015).

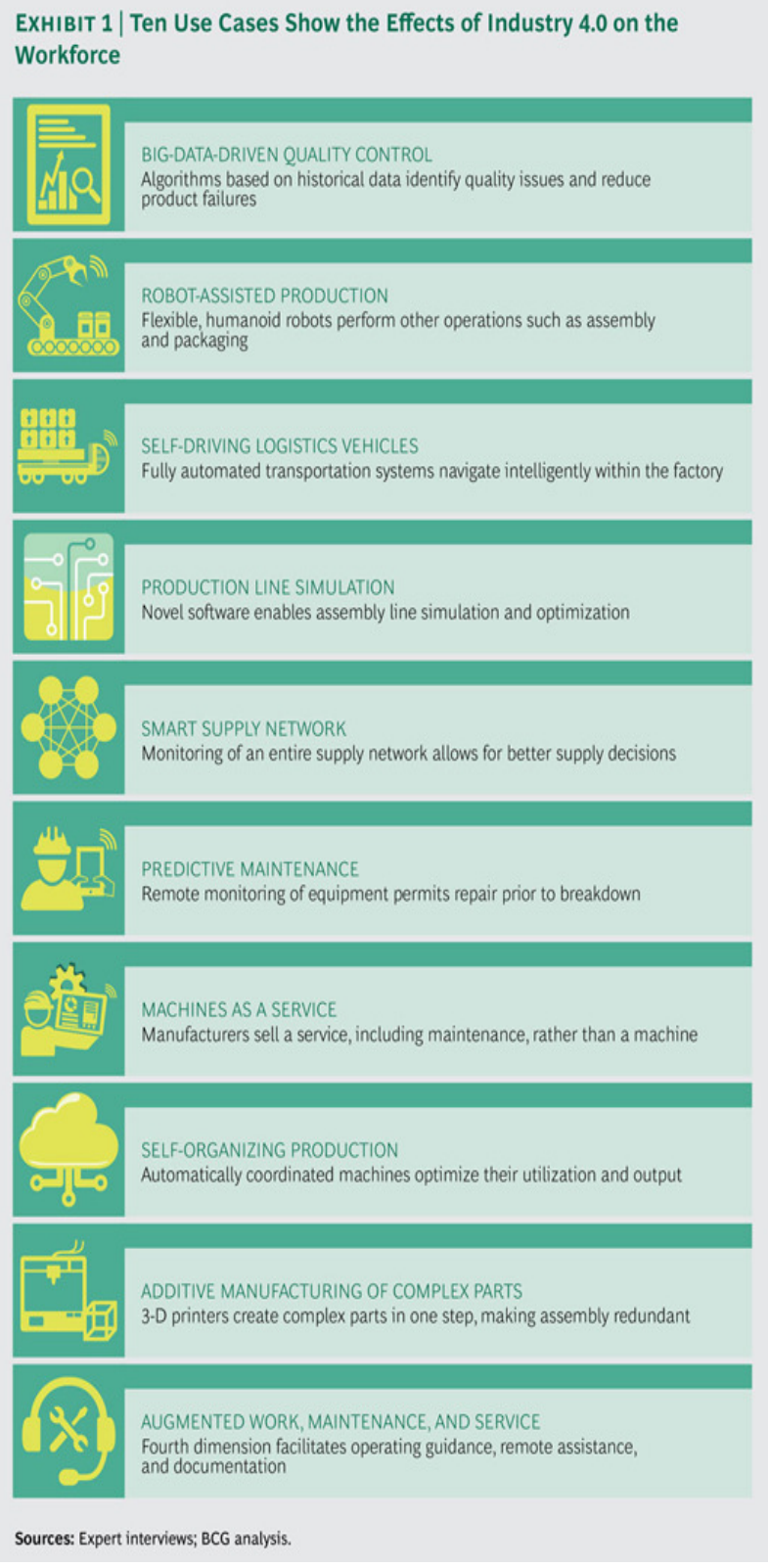

Fig. 1. Ten use cases show the effects of industry 4.0 on the workforce (Source: Lorenz et al. 2015)

The challenge of Vidzeme Region (Latvia) is adjusting the quality and structure of its workforce to the challenges and opportunities arising in the era of global knowledge economy, which if ignored will make the region unable to compete in the conditions of open labour market and education supply (VIAA 2016; European Schoolnet 2014; LV Ekonomikas ministrija 2013a, 2013b; European Commission/EACEA/ Eurydice 2015).
EXHIBIT 1 | Nine Technologies Are Transforming Industrial Production

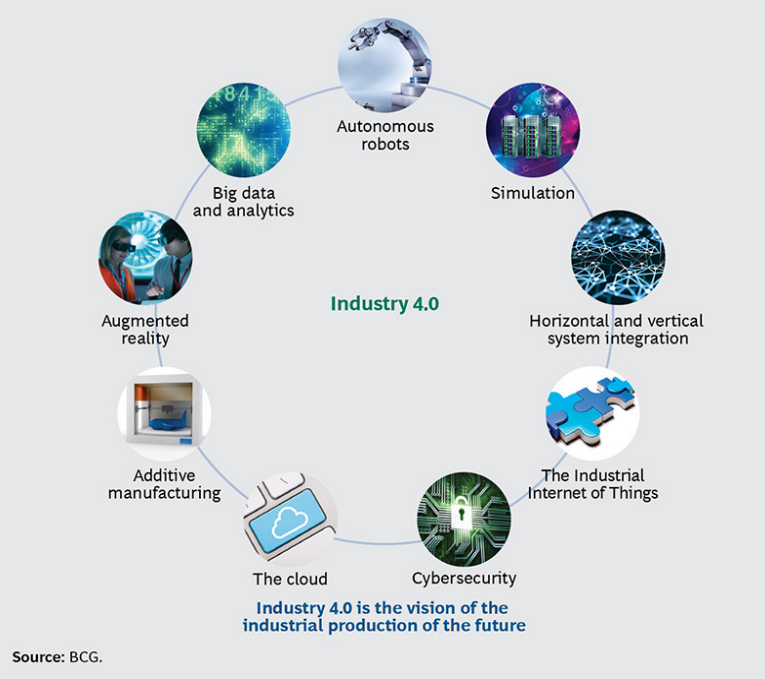

Fig. 2. Nine Technologies Transforming Industrial Production (Source: Rüßmann et al. 2015)

To address these issues, a study was conducted on "The Relevance of the Education offered in Valmiera and Vidzeme Region to the Demand of Employers and Employment Projections".

\section{Materials and methods}

In order to develop an employers' questionnaire and define questions for the experts on the future labour market in the region, and to make conclusions on acquired results, the following five information sources were used (see Fig. 3). To reach the goal, the group of researchers used both qualitative and quantitative research methods.

The quantitative research methods included an employers' quantitative survey.

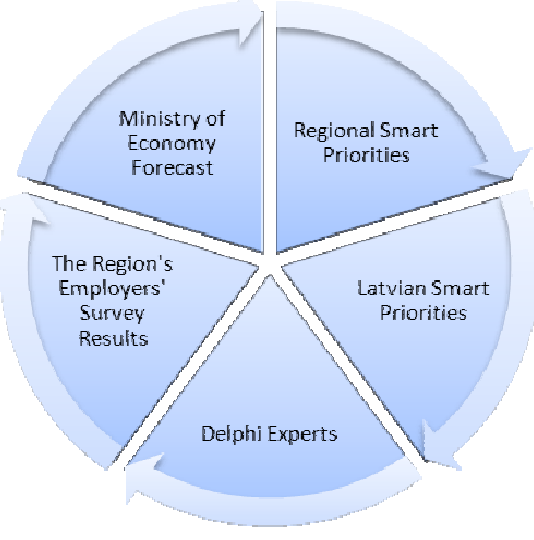

Fig. 3. Information sources for research of future labour market demand (Source: compiled by authors) 
According to the CSB (Central Statistical Bureau) 2014 data, the general set was formed by 16393 economically active enterprises of Vidzeme Region, employing 84.8 thousand employees (CSB 2015). In the general market sector, the most widely represented industries were agriculture, forestry and fishing (38\%), services (19\%) and trade $(11 \%)$. The number of active enterprises in the municipalities of Vidzeme Region varies. According to NACE2 Classifier, 18 industries are represented in total in Vidzeme Region. In municipalities and towns, the numerical relationships of companies of various sizes may vary, too.

The following basic principles were applied for selecting the sample groups (Vasermanis, Škiltere 2003).

- Stratified or typological case studies - initially the general set group is divided into subgroups, i.e. stratified - e.g. by sector, size, number of employees, territory and only then random selection group is made. The goal of this type of selection is to divide (stratify) the general group into more homogeneous groups, to reach a smaller dispersion and smaller error. Therefore, the general group is divided into typical, internally homogeneous as possible, but mutually exclusive groups or strata.

- After that unit selection is carried out within each group separately. Proportional sampling is the simplest and most precise when the number of units from each group is proportional to the size of the group. If the grouping is done by a research feature or related to it, the stratified sample represents all the general set groups as completely as possible.

- Random errors affect the final results of statistical observation. Random or representation (representative) errors, which may be random or systematic, occur if the sample does not fully represent the general set. Unfortunately, these errors cannot be avoided, however, by using probability theory methods, they can be minimised, and their boundaries can be determined with sufficient accuracy. In case of such errors the performance elements of the sample and the general set groups do not correspond.

- Systematic sampling errors result from incorrect of overly simplistic sampling; therefore, it should be provided that all units of the general set have equal opportunity to be included into the sample. This can be achieved by careful selection of the sample.

- For simple non-repetitive sampling random errors are calculated by the formula:

$$
\Delta_{x}^{-}=t \sqrt{\frac{s^{2}}{n}\left(1-\frac{n}{N}\right)},
$$

while the number of necessary units for simple non-repetitive sampling is calculated by the formula:

$$
n=\frac{t^{2} s^{2} N}{t^{2} s^{2}+\Delta \frac{2}{\bar{x}} N},
$$

where $\Delta_{\bar{x}}^{2}$ - permissible random error; $t$ - probability factor; $s^{2}-$ random dispersion; $N$-number of units in general set.

- The size of sample of each activity was calculated by the total sample size calculation according to the total number of companies by the following formula:

$$
n_{i}=n \cdot \frac{N_{i}}{N},
$$

where $n_{i}$ - sample size by activity, $n-$ total size of the sample, $N_{i}$ - size of the general set by activity, $N$ - total size of the general set.

- Multi-stage sample size should be increased by at least $10 \%$ of the estimated size, as multi-stage selection increases the random error.

Therefore, a proportional typological twostage selection was developed for the research corresponding to the general set - all economically active enterprises of Vidzeme Region. These factors encourage the choice of stratified sampling method. Selection of employers is built on a combined typological and random selection. The first level sampling is made as a three-stage stratified selection by the following criteria:

- sector in which the company operates;

- size of the company (micro, small, medium, large);

- territorial coverage (county).

The size of the general set of activity corresponds to the number of economically active companies in a particular sector. Sample size $=376$ and size of the general set $=16393$. Confidence probability of sampling results $p=0.95$, Margin of Error $=5 \%$. 
To minimise the probability of error, the first level selection was increased by $54 \%$, and it consists of 579 companies. Respondents, who complete the questionnaires, create the second level random selection (self-selection). The $2^{\text {nd }}$ level sample consists of 147 respondents, employing 9886 people and representing 18 sectors. Employers' questionnaire included general information about the company, the company's current performance characteristics and company's plans regarding attraction of workforce in the future and the required competences of the employees. By size, the companies were classified according to the definition of small and medium enterprises of EU Regulation 364/2004 I (European Union 2004).

The selection of the first level sample set according to the listed criteria was performed by the Central Statistical Bureau of Latvia. Respondents, who completed the questionnaires, formed the second level random sample (self-selection). The second level sample consists of 147 respondents.

The combined two-stage typological and random samplings do not match $100 \%$.

Table 1. Comparison of the general set group, combined two-stage typological and random sampling (Source: CSB 2015, compiled by authors)

\begin{tabular}{l|c|c|c}
\hline & $\begin{array}{c}\text { General } \\
\text { set }\end{array}$ & $\begin{array}{c}1^{\text {st }} \text { level } \\
\text { sample }\end{array}$ & $\begin{array}{c}2^{\text {nd }} \text { level } \\
\text { sample }\end{array}$ \\
\hline Number of companies & 16393 & 579 & 147 \\
\hline Number of employees & 84800 & 16583 & 9886 \\
\hline Number of sectors & 18 & 18 & 18 \\
\hline Number of counties & 26 & 26 & 26 \\
\hline
\end{tabular}

The most precise selection characteristics are the number of interviewed employers with 84.8 thousand employees in the general set. According to the client's wishes, all the large enterprises of Vidzeme Region were included, thus the $2^{\text {nd }}$ level selection covers 9886 employees (see Table 1). This exceeds $99 \%$ confidence limit, which requires only 3966 employees for $2 \%$ random error. Sectorial and territorial coverage in the sample represents $100 \%$. Most of the surveyed 147 companies operate in sectors (C) Manufacturing (20\%), (A) Agriculture, Forestry and Fishing (18\%) un (G) Wholesale and Retail Trade; Repair of Motor Vehicles and Motorcycles (12\%). Overall, half of the surveyed companies operate in these three sectors. Division of the general set group is also very similar - (C) Manufacturing (19\%), (A) Agriculture, Forestry and Fishing (17\%) and (G) Wholesale and Retail Trade; Repair of Motor Vehicles and Motorcycles (13\%) (CSB 2015). Therefore, one can conclude that the sample is sufficiently representative.

We used Jot Form platform for the electronic questionnaire. Employers were interviewed in a uniform questionnaire, consisting of several blocks (Employers survey 2015). By size the companies were classified according to the definition of small and medium. The link to the online questionnaire was sent to the respondent's e-mail address and it meant that the form could not be filled accidentally by people who were not part of the sample. The respondent was given 5 days for filling in the questionnaire. If the reply was not received within 5 days, the respondent was repeatedly invited to fill in the questionnaire. If the respondent did not fill in the questionnaire within two weeks, he or she was contacted by phone and received the questionnaire again.

The study involved Vidzeme Region employers and Latvian experts, including entrepreneurs of various industries, local municipal leaders and staff members, Parliament Members of LR Saeima, heads of educational institutions and academic staff, scientists representing engineering and social sciences. During the research, we interviewed 37 experts - entrepreneurs, policy makers, representatives of educational institutions and researchers. Delphi method was held in two rounds. Experts did not communicate among themselves, they were asked to predict labour market trends over the medium term, after which the increase in the demanded occupations and professions which will lose its meaning. The first round of the replies was collated and the results sent to the experts once again offering a choice to agree or disagree with the following statements, or to offer a different scenario.

The stated objective of the specific research was: "to identify employers' needs of the future labour market in 5-7 years in Vidzeme Region". After verification of the selection of the first level sample set, the research group found out some inconsistency with matching real data about employers-micro size enterprises. Latvia has two level registrations for entrepreneurs who have 5 or less employees - some enterprise forms can be registered through The Register of Enterprises of the Republic of Latvia, but some are registered only at the local or regional level by the State Revenues Service of the CSB (insufficiently covered by data from Central Statistical Bureau of Latvia). This inconsistency was corrected in the second level random sample by correct weights without further general data verification issues.

To validate the results of quantitative analysis, we provided a wide range of expert interviews (37 
experts were interviewed by Delphi method). The results and outcomes from analysis of experts' evaluations proved the validity of the general conclusions, achieved by the statistical analysis, identifying employers' needs of the future labour market in 5-7 years in Vidzeme Region.

\section{Results and discussion}

\subsection{Characteristics of the future labour market}

Experts believed that there would be some brand new professions, but mostly changes would affect the contents of the existing professions and the required skills. Professionals with in-depth knowledge in specific sectors and variety of multifunctional skills will be needed. More and more opportunities to work remotely will affect the relationship between employees and employers making it more independent, requiring more responsibility and better personnel management skills from the employer.

In terms of the topicality of occupations during the next 5 years, the experts all agree on priority of information and communication services and related professions. The next most frequently mentioned is the processing industry, since a change in the working specifics will require employees who are able to use complicated equipment.

As everyone's ability to work with information technology, as well as an extensive free technology and software product offer will increase, it will change the contents of jobs of the IT specialists in a company, they will rather become consultants, or this service will be outsourced.

Some professions will not disappear altogether, but their role will grow, such as military experts, 3-D printing designers, professions related to the education and maintenance of immigrants, professions related to eco-production, scientists within new sectors of science. According to the experts, it will be affected by ever-growing integration of modern technologies both in production and daily life, as well as socio-economic processes, such as demography, urbanisation, migration, an aging population, health deterioration, unhealthy living habits, stress etc.

On the one hand, it can be expected that more focused and narrower specialisations will develop, for example, specialised consultants, care takers for certain age groups or people with certain diagnoses; on the other hand there will be multi-skilled workers able to adjust to various needs of the labour market, but more likely they will be on the top organisation and management level, such as project managers and coordinators etc. who create a team for the implementation of a certain project (Expert interviews 2015).

The experts emphasize that the Latvian market is relatively small and the specialisation will take place on an international level, this means that a Latvian specialist will work both in Latvia and abroad, depending on the job opportunities.

Professionals with in-depth knowledge in certain economic sectors and sub-sectors will be required, while it will be equally important for the employee to represent various skills - be a diplomat, seller, and industry professional. This will be influenced by increasing wider opportunities to work remotely.

According to the experts, the role of private institutions and alternative education will grow creating a demand for a new type of education professionals.

Regarding opportunities to work remotely, the contents and form of the work of lawyers, auditors, accountants and financiers will change. The experts believe that due to technological progress, demographic situation in the country and other socio-economic factors, a number of professions will disappear or their role will decrease, such as production line workers, sales assistants, cashiers, packers, drivers, pilots, conductors, cleaners, janitors, security guards, postmen.

For example, driving seems a safe profession at the moment as delivery of goods from door to door is not automated yet, and machines cannot yet be trusted with long distance freight transport; however, Google, Uber and Tesla are developing cars that are capable of driving themselves, starting with ones that can make long distances. If they succeed, transport and logistics companies will need a large, but single investment, and the role of driver's profession will decrease. The experts believe that forgotten and archaic professions and methods that ensure the basic needs of human existence will revive. This will be encouraged by the negative impact of current intensive pace of life on the psyche of many people, as well as dissatisfaction with industrially produced products (quotation from an expert interview). The significance of home production, handicraft will formalize and grow even more.

The experts justly point out that the need to work with the local community will become urgent. The cause of Latvia's adversity is people's disbelief in them, thus the work with community is very significant. Public administration is expected to be deinstitutionalized and bureaucracy will decrease. It means, more power will be given in the hands of people (quotation). 
The most important conditions that will affect the content change of the labour market in the future are:

- The world is becoming a global economy, superpowers struggle for dominance in the world.

- Socio-economic processes: migration, social stratification, demographics and aging of population.

- Increase in the demand for food.

- Merging of political environment with the criminal world. Increase of data security problems.

- Rapid technological progress, including military technologies.

- Deterioration of emotional and physical health.

\subsection{Analysis of shortage of qualitative labour}

113 or $78 \%$ of surveyed 147 employers have experienced, but $32 \%$ or $22 \%$ have not experienced the lack of qualitative staff. This is due, primarily, to small number and density of the population and in the municipalities of Vidzeme region.

The following section analyses the reasons for the lack of skilled labour.

Most frequently (52\%) the employers state "insufficient number of skilled workers in the neighbourhood" as the reason for the lack of qualified labour (see Fig. 4). The next most important reasons are "applicant's/employee's lack of practical skills in the profession" (43\%) (see Fig. 5) and "insufficient education of applicant/ employee" (31\%), as well as "salary expectations of applicant/ employee are too high" (24\%) (see Fig. 6).

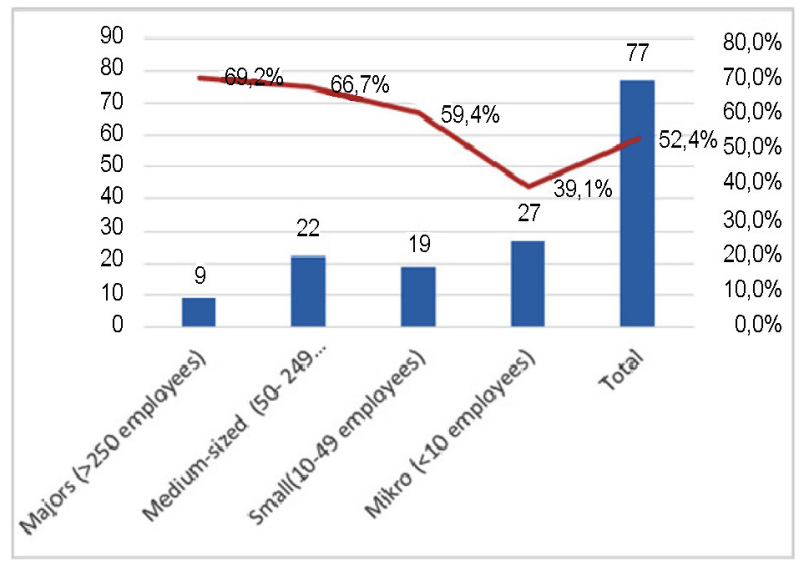

Fig. 4. Insufficient number of skilled workers in the neighbourhood (Source: Employers survey 2015, $\mathrm{n}=147$, compiled by authors)

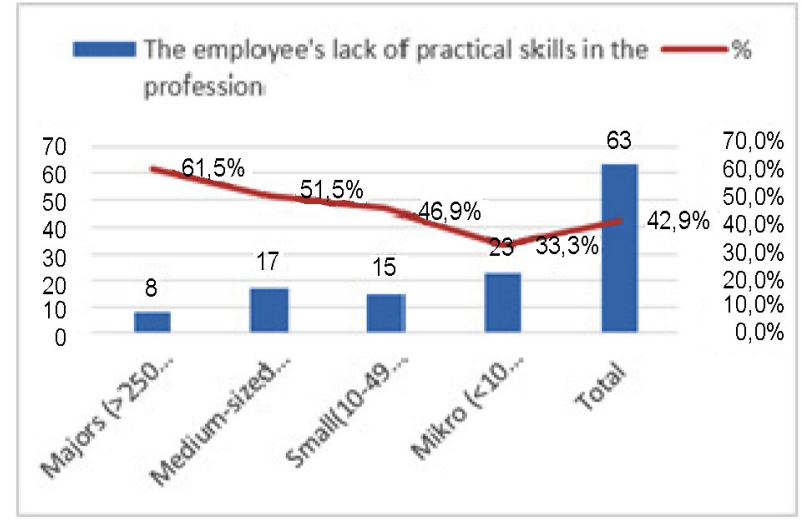

Fig. 5. Workers' lack of practical skills in the profession (Source: Employers survey 2015, $\mathrm{n}=147$, compiled by authors)

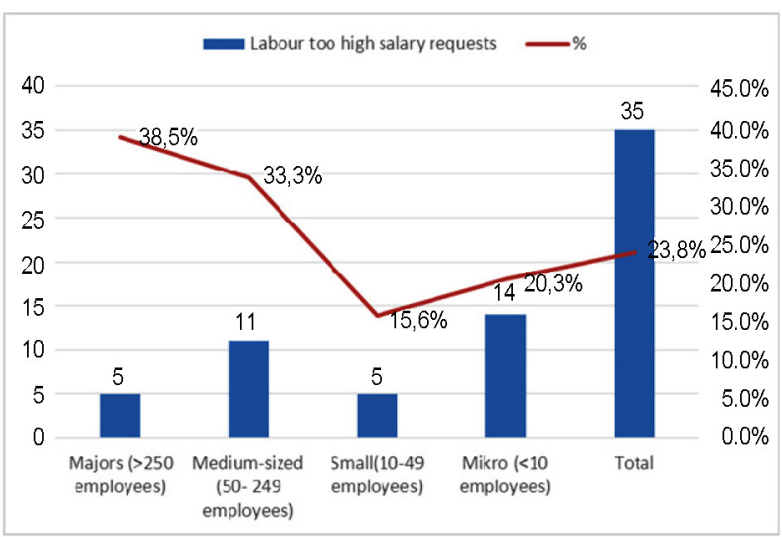

Fig. 6. Too high salary expectations (Source: Employers survey $2015, \mathrm{n}=147$, compiled by authors)

There are great opportunities for lifelong learning. The entrepreneur has to learn, but not by spending two years in a school chair; there should be courses available for working people, for example half an hour every day. The attention should be more directed towards retraining people who want to work. How to retrain a good turner who does not know the novelties - the trainers have to go to the company and train him there. The trainer goes to the entrepreneur (Expert interviews 2015).

$23 \%$ of employers indicate that the recruitment of workforce is no problem. Among them almost a third of them are micro-enterprises, and more than a fifth - small enterprises.

This group of companies includes many family businesses and the self-employed, where the company's workers are members of one family and children take over the parents' professions and skills. In particular, there are many such enterprises in agriculture, forestry and fishing, service sector, construction (Rozentāle et al. 2015; Līviņa 2015; Broka et al. 2015). 2 or $15 \%$ of large companies and $9 \%$ of medium-size companies have 
admitted that there are no problems in recruiting labour force. From the surveyed 101 small and micro enterprises one third of the micro enterprises and one fifth of the small enterprises have no problems with recruitment of staff.

\subsection{The most demanded profession groups}

In order to find out which profession groups will be required, the employers were asked a question: What professions will be needed in the next 5-7 years?

The questionnaire contains questions on 10 profession groups that are included in Classification of Professions. The groups "senior specialists and specialists" and "specialists" are combined in one:

- 0 professions of National Armed Forces;

- 1 managers;

- 2 senior specialists and specialists;

- 3 clerks;

- 4 service and sales workers;

- 5 skilled agriculture, forestry and fishery workers;

- 6 qualified workers and craftsmen;

- 7 plant and machine operators and assemblers;

- 8 manual workers.

In total the surveyed 147 employers will need 678 new employees, the most required of whom during the next 5-7 years will be workers in the profession group "senior specialists and specialists" (see Fig. 7).

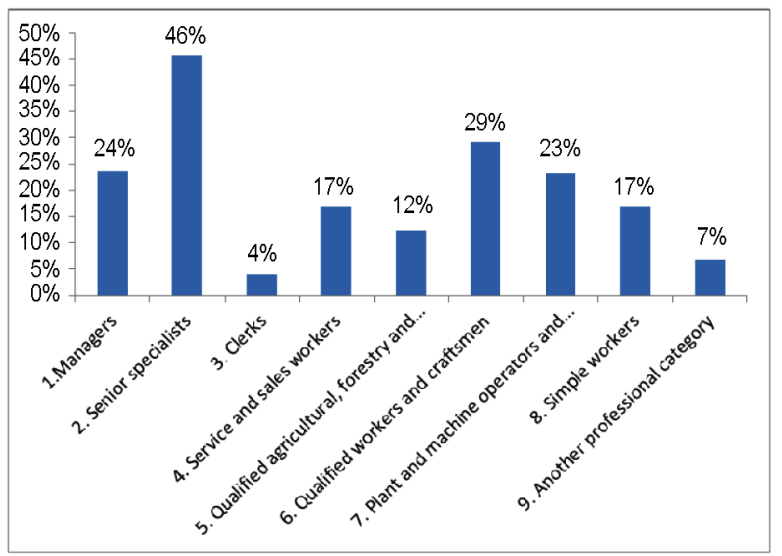

Fig. 7. Demanded occupational groups (Source: Employers survey 2015, $\mathrm{n}=147$, compiled by authors)

Of all required new employees 272 or $40 \%$ will be senior specialists and specialists. The next most demanded profession group will be qualified workers - there will be 122 new workers needed or $18 \%$ of all new staff. This is followed by manage- rial profession group (there will be 99 of those needed, i.e. $15 \%$ of all new employees). The economic sectors that will mostly require senior specialists and specialists will be Manufacturing, Human Health and Social Work Activities, Public Administration and Defence; Compulsory Social Security, Administrative and Support Service Activities.

Experts have also noted the need of managers. A refined managerial talent will be required, as well as professionals with excellent managerial skills and experience, ideally with international experience, modern education, efficient managers, leaders. There is a lack of employees with managerial skills and competences. Entrepreneurs will be able to accept and overcome the economic troubles of today: low productivity, lack of human resources, low population density. They will not be afraid to work in the digital business environment, selling their products all over the world (Expert interviews 2015). Managers able to coordinate the technical side of the company will be required (Expert interviews 2015).

As regards sales management professions, it will be required that they can attract customers. In the profession it is necessary to acquire the knowledge of the design of goods and services, the importance of a brand in sales, quality experience building, greater involvement of the customer in the creation process of products and services. The professions will become technology and knowledge intensive (Expert interviews 2015).

The economic sectors requiring managers most will be Wholesale and Retail Trade; Repair of Motor Vehicles and Motorcycles, Human Health and Social Work Activities.

Plant and machine operators and assemblers group will need 72 , i.e. $11 \%$ of total number of the required employees. It is followed by Services and sales workers group (it will require 49 , i.e. $7 \%$ of new employees), and simple manual workers group (it will require 28 , i.e. $4 \%$ of new employees). Skilled agricultural, forestry and fishing workers group takes 7 th place. It will need 19 , i.e. $3 \%$ of new employees, but clerks group will need 17 , i.e. $2.5 \%$ of all required employees.

The comparison of Vidzeme region employers' survey results with the Latvian Central Statistical Bureau data shows that the trend of recent years in Vidzeme is similar to the trend in Latvia in general when more professionals and fewer support service workers are recruited (CSB 2015).

In a recent study by the large U.S. online job site, CareerBuilder, more than half the employers surveyed had positions for which they could not 
find qualified candidates: $71 \%$ had trouble finding information-technology specialists, $70 \%$ engineers, $66 \%$ managers, $56 \%$ health-care and other specialists, and $52 \%$ financial operations personnel. Nearly half of small and medium-size employers say they can find few or no "qualified applicants" for recent vacancies, according to the latest survey by the National Federation of Independent Businesses (Lewis 2015).

\section{Conclusions}

The demand for professions in the sectors where it is difficult or impossible to replace human work with technology will increase. The demand for professions where it is necessary to use technologies, but which require the presence of human work/ intelligence will also grow. An alternative trend will develop, too - people will purposefully avoid technologies, return "back to nature", create and choose jobs that have minimum contact with active participation in the information space.

Professions that will be most required: engineers, construction workers and related professionals, control specialists of technological processes, wood workers, managers in the field of information and communication technology, managers in the field of sales, marketing and development, machine mechanics and repair locksmiths, decoration building workers, managing directors and corporate executives, programmers and software developers and analysts, and financial professionals.

Demand for the medical professions will grow. The region has a shortage of medical workers, as professionals leave for work abroad due to low salaries in Latvia. People in general are becoming more susceptible to diseases driven by people's tendency to move to cities, as well as unhealthy lifestyle, the food we eat, daily lack of exercise, stress, aging of the population. There will be a growing demand for specialists that help individuals to be proactive in order to avoid health problems or to handle them in early stages - trainers of various physical activities, couches, psychologists and psychotherapists.

There will be a need for people who promote the cooperation among entrepreneurs, and between entrepreneurs and research institutions, universities, such as business psychologists, mediators, customer experience creators, business engineers, the labour agency or "head hunters".

The growing number of micro enterprises and the self-employed will create demand for the services of agents and middlemen.
There will be a growing need for specialists working with children with special needs. Specialists will be required who will teach people how to communicate, self-organize in order not to fall into depression and be able to cope with the environment around us and fit into it, knowledge and training on how to live "happily".

The current situation with refugees will also require professionals for refugee integration in our society, psychologists, additionally trained security and social workers.

\section{Acknowledgements}

The group of researchers express their sincere gratitude to all 37 experts and 147 employers who responded and participated in the study.

This work was supported by the Valmiera City Council research grant; National Research Program 5.2. "Economic Transformation, Smart Growth, Governance and Legal Framework for the State and Society for Sustainable Development - a New Approach to the Creation of a Sustainable Learning Community (EKOSOC-LV)".

\section{References}

Bessen, J. 2015. Toil and technology: innovative technology is displacing workers to new jobs rather than replacing them entirely, IMF Finance and Development Magazine 5: 16-19.

Bresnahan, T.; Brynjolfsson, E.; Hitt, L. 2002. Information technology, workplace organization and the demand for skilled labour: firm level evidence, Quarterly Journal Economics of Harvard College and the Massachusetts Institute of Technology 117: 339-376.

Broka, A.; Rozentale, S.; Livina, A.; Rocans, K. 2015. Par vietējās pārtikas ražošanas nozares, amatniecības, nepārtikas mazo, mikro uzn̄èmumu, $k \bar{a}$ arī pakalpojumu sniegšanas attīstības atbalstu un iespējām Cēsu rajona lauku partnerības teritorijā [About the local food industry, crafts, small and micro enterprises, as well as service development support and opportunities Cesis District Rural Partnership territory] [online]. A report commissioned by NGO Cēsu Rajona Lauku Partnerība. [cited 4 February 2016]. Available from Internet: http://www.partneriba.lv/useruploads/files/ gala_zinojums_final_03_07_15.pdf

Brynjolfsson, E.; McAfee, A. 2014. The second machine age: work, progress, and prosperity in a time of brilliant technologies. New York: W.W. Norton \& Company.

Brynjolfsson, E.; Saunders, A. 2010. Wired for innovation: how information technology is reshaping the economy. Massachusetts Institute of Technology. 
Employers survey [online] 2015 [cited 4 March 2016]. Available from Internet: https://form.jotform.com/form/52634331477961

European Commission/EACEA/Eurydice 2015. The European higher education area in 2015. Publications Office of the European Union, Luxembourg.

European Schoolnet. 2014. The e-skills Manifesto. EUN Partnership AISBL, Belgium.

European Union. 2004. Commission Regulation (EC) No 364/2004, Official Journal of the European Union 2004(2): 27-29.

Ford, M. 2015. Rise of the robots: technology and the threat of a jobless future. New York: Basic Books.

Goos, M.; Manning, A. 2007. Lousy and lovely jobs: the rising polarization of work in Britain, The Review of Economics and Statistics 89(1): 118-133 http://dx.doi.org/10.1162/rest.89.1.118

Goos, M. 2013. How the world of work is changing: a review of the evidence, in International Symposium for Employers on the Future of Work, 5-6 December 2013, Geneva, Switzerland [online], [cited 4 March 2015]. Available from Internet: www.ilo.org/employersymposium

Katz, L. F.; Margo, R. A. 2013. Technical change and the relative demand for skilled labor: the United States in historical perspective. NBER Working Paper 18752.

Krone, A; Klavis, A.; Zemite, A.; Zauers, A. 2016. When the time comes, the machine will carry out everything? Kapitāls 217(1): 107-110.

Lewis, M. A. 2015. Robots don't mean the end of human labor, The Wall Streat Journal 23(8): Europe Edition.

Lindzon, J. 2015. Welcome to the new era of human resources, FastCompany Magazine (5).

Līvina, A. 2015. Cultural environment development, preservation of the nature diversity and urbanisation processes within the context of the balanced development of Latvia: Thesis of the EKOSOC LV 5.2.8. research. Latvian Academy of Sciences.

Lorenz, M.; Rüßmann, M.; Strack, R.; Lueth, K. L.; Bolle, M. 2015. Man and machine in industry 4.0: how will technology transform the industrial workforce through 2025? Boston Consulting Group.
LR Central Statistical Bureau (CSB). 2015. Economically active enterprises by size group in statistical regions [online], [cited 10 October 2015]. Available from Internet:

http://www.csb.gov.lv/statistikas-temas/statistikasuznemumu-registrs-galvenie-raditaji-30076.html

LV Ekonomikas ministrija. 2013a. Informatīvs ziņojums par darba tirgus vidēja un ilgterminga prognozēm [The informative report on the labor market in the medium and long-term forecasts].

LV Ekonomikas ministrija. 2013b. Pētījums Nākotnē stratēgiski pieprasītākās prasmes Latvijā [Study the future strategic requested skills in Latvia].

Mokyr, J.; Viekers, C.; Ziebarth, N. L. 2015. The history of technological anxiety and the future of economic growth: is this time different?, Journal of Economic Perspectives 29(3): 31-50. https://www.aeaweb.org/issues/381

OECD. 2015. OECD Employment Outlook 2015, Paris.

Rifkin, J. 1995. The end of work. New York: Putnam's Sons Publishing.

Rozentāle, S.; Ore, M.; Krūmin̦a, I.; Krūmin̦š, G., Melbarde, V. 2015. Economic transformation, smart growth, governance and legal framework for the state and society for sustainable development - a new approach to the creation of a sustainable learning community: Thesis of the research EKOSOC-LV 5.2.3. Latvian Academy of Sciences.

Rüßmann, M.; Lorenz, M.; Gerbert, P; Waldner, M.; Justus, J.; Engel, P.; Harnisch, M. 2015. Industry 4.0: the future of productivity and growth in manufacturing industries [online], [cited 8 February 2016]. Available from Internet:

http://www.iariajournals.org/software/soft_v8_n34 _2015_paged.pdf

State Education Development Agency (VIAA). 2016. World profession [online], [cited 10 October 2015]. Available from Internet: www.profesijupasaule.lv

Vasermanis, E.; Šķiltere, D. 2003. Probability theory and mathematical statistics. Latvian University, Rīga.

World Economic Forum 2016. The future of jobs [online], [cited 8 February 2016]. Available from Internet: http://www3.weforum.org/docs/Media/ WEF_Future_of_Jobs_embargoed.pdf 